\title{
Whitefly (Bemisia tabaci) Management Program for Ornamental Plants ${ }^{1}$
}

\author{
Vivek Kumar, Muhammad Z. Ahmed, Cristi Palmer, Cindy L. McKenzie, and Lance S. Osborne²
}

Bemisia tabaci (Gennadius), commonly known as silverleaf whitefly, is a polyphagous pest and listed as one of the world's 100 worst invasive species (Lowe et al. 2000). It is known to feed on more than 1000 plant species and vector over 120 plant-damaging viruses (Jones 2003; Li et al. 2021). The pest status of $B$. tabaci is complicated because of their widely debated taxonomic status, previously identified as consisting of numerous "biotypes" (biotypes are groups of organisms sharing the same specific genetic makeup) but now considered as 40 or more discrete but morphologically indistinguishable cryptic species (Jiu et al. 2021). Only a handful of countries have escaped the cosmopolitan distribution and subsequent establishment of the worst of these: B. tabaci Middle East-Asia Minor 1 (MEAM1) and Mediterranean (MED), also known as biotypes B and Q, respectively. MEAM1 (B-biotype) was first detected in Florida in 1986 in poinsettia greenhouses and quickly moved to the field, causing unprecedented losses to vegetable, field, and ornamental crops (Parrella et al. 1992). MEAM1 rapidly spread across the southern United States to Alabama, Arizona, California, Georgia, Louisiana, Mississippi, New Mexico and Texas, , where severe field outbreaks occurred during the early 1990s on melons, cotton, tomato, and other vegetable crops (Perring et al. 1993).
MED (Q-biotype) was first documented in the United States in 2004 (Dennehy et al. 2005) in Arizona, and in 2005 in Florida (McKenzie et al. 2009). Since then it has been reported from 28 states as a pest in greenhouses (McKenzie et al. 2020) but was not previously reported to have escaped protected culture (McKenzie and Osborne 2017). However, there have been 215 positive confirmed detections of MED since April 2016 from 15 counties in Florida (McKenzie and Osborne 2017; FDACS-DPI Database 2021). Of the 215, 190 came from nurseries and plant outlets, two from field locations, and the rest from outdoor residences in Palm Beach and Miami-Dade counties. Considering its dispersal abilities (direct and indirect through transportation of infested materials), damage potential, and the wide range of host crops (vegetable or ornamental) grown in Florida, MED could cause serious economic impacts to Florida growers and consumers nationwide were populations to establish in various production areas. This is because of the reduced susceptibility of these whiteflies to a variety of insecticides, including some of the chemical classes (neonicotinoids and insect growth regulators) most widely used for whitefly control (Horowitz et al. 2004).

1. This document is ENY989, one of a series of the Entomology and Nematology Department, UF/IFAS Extension. Original publication date April 2017. Revised August 2021. Visit the EDIS website at https://edis.ifas.ufl.edu for the currently supported version of this publication.

2. Vivek Kumar, post doctoral associate, Entomology and Nematology Department, UF/IFAS Mid-Florida Research and Eduation Center; Muhammad Z. Ahmed, United States Horticulture Research laboratory, ARS-USDA; Cristi Palmer, IR-4 Project Headquarters, Rutgers University; Cindy L. McKenzie, United States Horticulture Research laboratory, ARS-USDA; and Lance S. Osborne, professor,Entomology and Nematology Department, UF/IFAS MFREC; UF/IFAS Extension, Gainesville, FL 32611.

The use of trade names in this publication is solely for the purpose of providing specific information. UF/IFAS does not guarantee or warranty the products named, and references to them in this publication do not signify our approval to the exclusion of other products of suitable composition.

The Institute of Food and Agricultural Sciences (IFAS) is an Equal Opportunity Institution authorized to provide research, educational information and other services

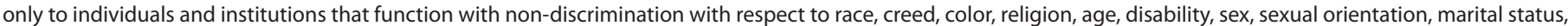

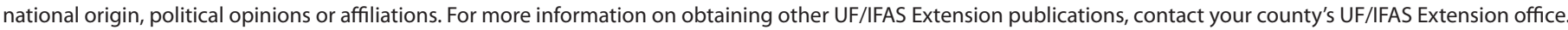
U.S. Department of Agriculture, UF/IFAS Extension Service, University of Florida, IFAS, Florida A \& M University Cooperative Extension Program, and Boards of County Commissioners Cooperating. Nick T. Place, dean for UF/IFAS Extension. 
Considering the known economic impact of MEAM1 and the potential impact of MED on ornamental growers, we developed a management program for both species. The program does not require a pesticide application when the first whitefly adult is detected. Rather, it outlines steps to manage and maintain whitefly populations throughout the initial propagation and active growth stages at levels that will minimize numbers on the final plant material being shipped.

Ornamental plant growers should apply pesticides when scouting reports identify population densities at levels where experienced and/or Extension personnel indicate action should be taken. These densities would depend on many factors including the crop, source(s) of infestation, and environmental conditions.

This publication is intended to provide a management program for nursery and ornamental plant growers to aid in their efforts to minimize selection for insecticide resistance irrespective of whitefly biotype while helping to achieve top-quality plant materials.

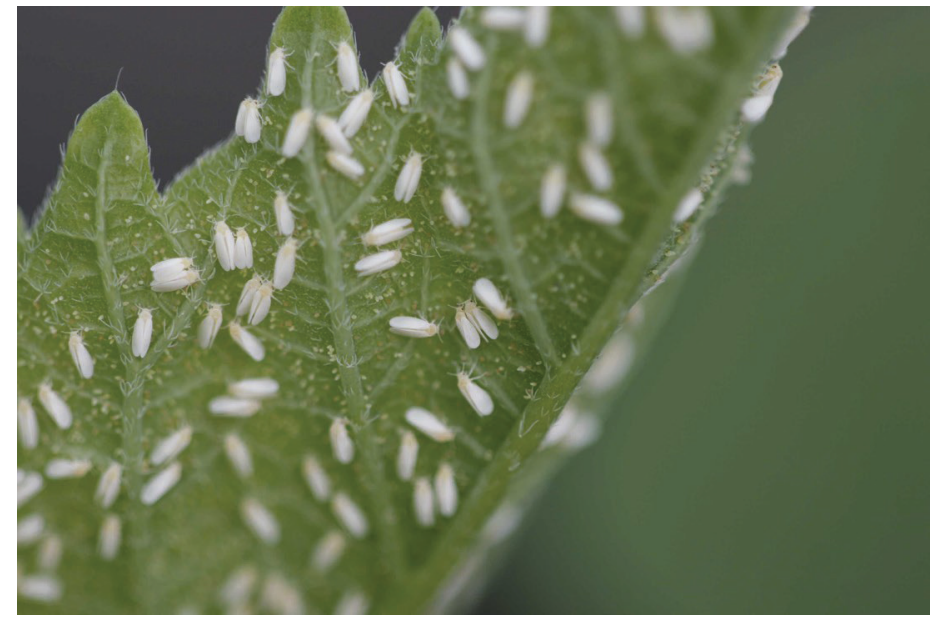

Figure 1. Whitefly, Bemisia tabaci Gennadius, eggs and adults. Credits: Lance S. Osborne, UF/IFAS

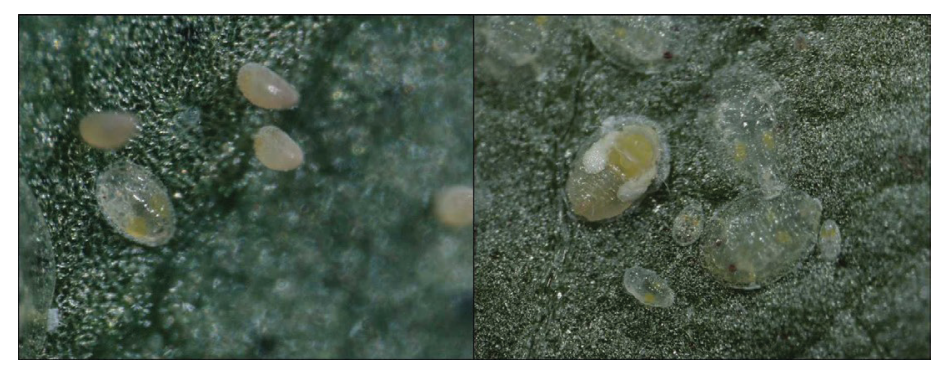

Figure 2. Whitefly, Bemisia tabaci Gennadius, immature stages. Credits: Lance S. Osborne, UF/IFAS

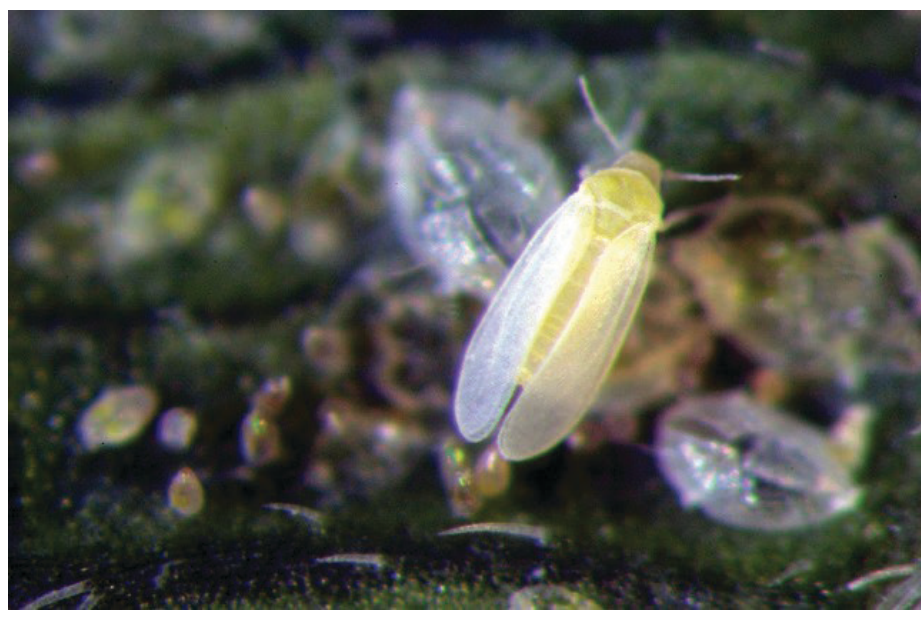

Figure 3. Whitefly, Bemisia tabaci Gennadius, adult. Credits: Lance S. Osborne, UF/IFAS

\section{Hosts and Damage}

Whiteflies feed on plant phloem by injecting enzymes and removing the sap, reducing the vigor of the plant, or, in cases of severe infestation, killing the host. Greenhousegrown ornamentals such as poinsettia, hibiscus, ivy, gerbera daisy, lantana, verbena, garden chrysanthemum, salvia, and mandevilla are especially susceptible to whitefly damage. Honeydew excretions from the whitefly feeding promote the growth of sooty mold, which also significantly reduces plant quality. The most obvious whitefly feeding damage symptoms are stem blanching, chlorotic spots, leaf yellowing, and shedding. In many crops, the damage caused by $B$. tabaci is indirect, i.e., by transmitting diseasecausing viruses. The following table compares biological characteristics of the three cryptic species of B. tabaci found in the United States and indicates that the invasive MEAM1 and MED are more destructive pests and have wider host ranges compared to the native New World (NW) species (A-biotype). Between the two invasive B. tabaci species, MEAM1 has greater adaptability to different regions and ability to cause plant disorders, whereas MED has greater tolerance to insecticides than MEAM1.

\begin{tabular}{|c|c|c|c|}
\hline \multirow[t]{2}{*}{ Pest characteristics } & \multicolumn{3}{|c|}{ Cryptic species } \\
\hline & NW & MEAM1 & MED \\
\hline Host plant range & $X^{*}$ & $X X X X$ & $X X X X$ \\
\hline Biotic potential & $X X$ & $X X X X$ & $X X$ \\
\hline Tomato Yellow Leaf Curl Vector & $x$ & $X X X$ & $x X$ \\
\hline Plant disorders & - & $X X X X$ & $x$ \\
\hline Insecticide resistance & $x$ & $X X$ & $X X X X$ \\
\hline
\end{tabular}




\section{Management Recommendations}

There are three major goals of a successful whitefly management program: 1) to help growers produce a high-quality, marketable crop for the consumer; 2) to preserve the effectiveness of the chemical tools used to manage whiteflies; and 3) to prevent the spread or distribution of difficult-to-control and possibly pesticide-resistant populations. If we do not maintain the viability of effective chemical tools, the wide host plant range of this pest will make it difficult for growers to produce and landscapers to obtain many popular ornamental species. Consequently, the wise use of chemicals through a scientifically based Integrated Pest Management (IPM) program is essential in today's global setting. It is important to consider that the MED whitefly is already resistant to a number of commonly used insecticides. Non-judicious use of chemicals could also easily lead to increased MEAM1 resistance and make the existing problem worse. In response to the potential economic impacts of whitefly invasion, a consortium of entomologists from different organizations developed the Whitefly Management Program in 2006. The program provides guidance on best management practices, including scouting, sanitation, exclusion, biological control, and chemical control. Check with your local UF/IFAS Extension agent or specialist for the latest management recommendations targeting MEAM1 or MED whitefly.

The following subsections outline the steps of a whitefly IPM program that can effectively reduce growers' reliance on anti-whitefly chemicals and insecticides.

\section{Detection/Scouting}

Regular scouting is essential to detect whitefly incidence and avoid economic damage. Crops must be inspected at weekly intervals to find infestations early. Monitor whitefly population levels by trapping winged adults on sticky cards or inspecting leaves for the presence of adults and immatures. Strategically place yellow sticky cards throughout the greenhouse, especially near doors and among new plants to provide information about the presence and movement of whiteflies. Detect whiteflies on plants by randomly selecting 10 plants per 1,000 square feet of greenhouse space and thoroughly examining these plants on the underside of leaves for the presence of whitefly adults, nymphs, and eggs. Whitefly eggs are generally concentrated on new leaves of the host, and nymphs are usually found on the older leaves, so a good population estimation of whiteflies can be made by sampling leaves from different parts of the plants. A 10x hand lens may be needed to see eggs or small nymphs. Because the recommended management practices for the two biotypes may vary, it is important to determine the whitefly biotype before applying any chemical in the affected region. The contact information for the laboratory authorized to biotype whiteflies in Florida is presented below. Density levels requiring treatments vary depending on factors including the crop, source of infestation, history of disease transmission, and environmental conditions.

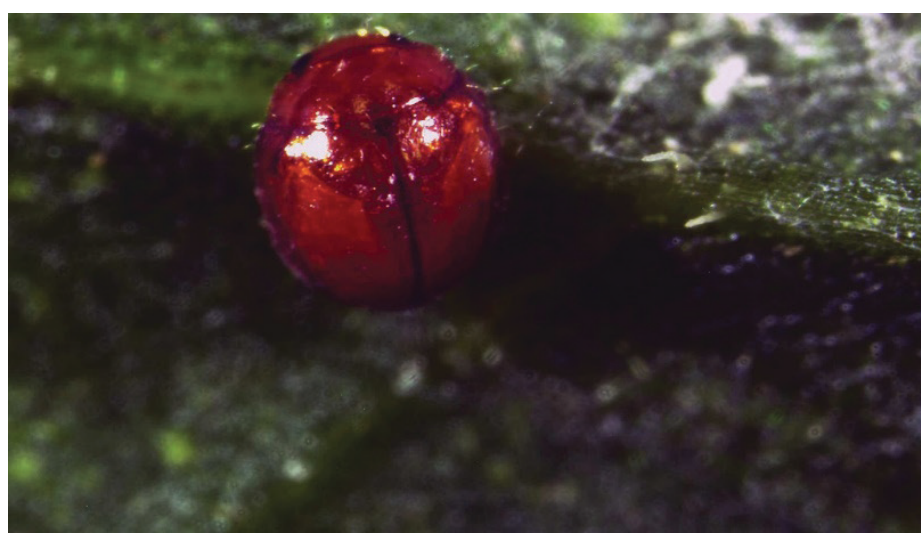

Figure 4. Predatory beetle, Delphastus pallidus adult. Credits: Lance S. Osborne, UF/IFAS

\section{Sanitation}

Remove sources of infestation (weeds, old plant debris, and growing medium) from within and around the greenhouse or nursery that might carry over populations from one season to the next. While disposing of affected plant materials, place debris into a sealed bag or container, and discard it in a safe place immediately. Because pests are often dispersed via transport of infested materials, be careful not to carry infested plant material or debris unsealed in an open truck/ vehicle.

\section{Exclusion}

To prevent whiteflies from entering the greenhouse, seal or screen openings with appropriate screening material.

Whiteflies are small, so screens with a hole size of 0.27 $\mathrm{x} 0.82 \mathrm{~mm}$ are required to exclude them. If possible, construct the facility so that workers enter through an anteroom.

\section{Cultural Control}

Grow plants so as to facilitate good pesticide coverage. If possible, try to have a crop-free period to break any cycling within the nursery and install trap crops, e.g., squash, melons, or something from seed that grows fast to divert incoming whitefly populations. 


\section{Biological Control}

Several biological agents are available for managing $B$. tabaci including predators (the mite Amblyseius swirskii, or the insects Delphastus catalinae and lacewing larvae), parasitoids (Eretmocerus eremicus, Encarsia spp.) or entomopathogenic fungi (Beauveria bassiana, Cordyceps fumosorosea). Before applying any biocontrol agents (BCA), it is important to check with commercial vendors of BCA for their compatibility with chemicals and environmental requirements such as temperature, humidity, and day length. BCAs may not control an existing high population of whiteflies before significant crop damage occurs, so early application of agents before high pest buildup is recommended. Use of generalist predators can provide control of B. tabaci along with other pests of ornamentals. In Florida, B. tabaci is effectively managed on ornamentals and vegetables grown in greenhouses with Encarsia sophia. In our recent greenhouse studies focused on integrated management of MED on salvia and mint crops, we observed the predatory mite A. swirskii and parasitic wasp E. eremicus to be very efficient in managing this pest, respectively. Consult with your local UF/IFAS Extension specialist about the suitable biocontrol agents available for a specific crop.

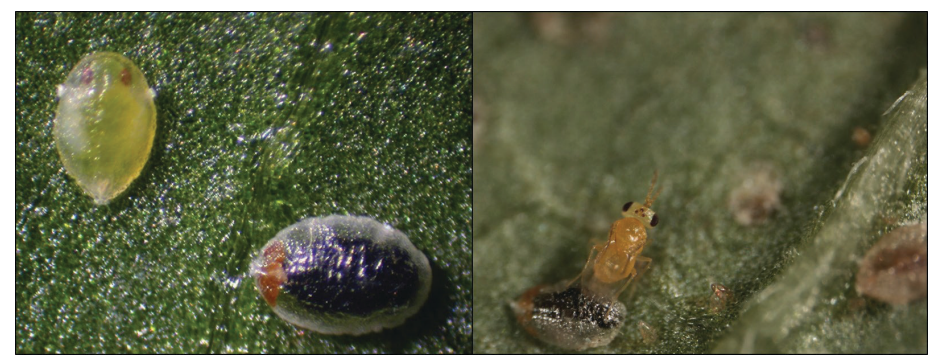

Figure 5. Bemisia tabaci nymph parasitized by parasitic wasp, Encarsia sophia (on left), parasitoid emerging (on right).

Credits: Lance S. Osborne, UF/IFAS

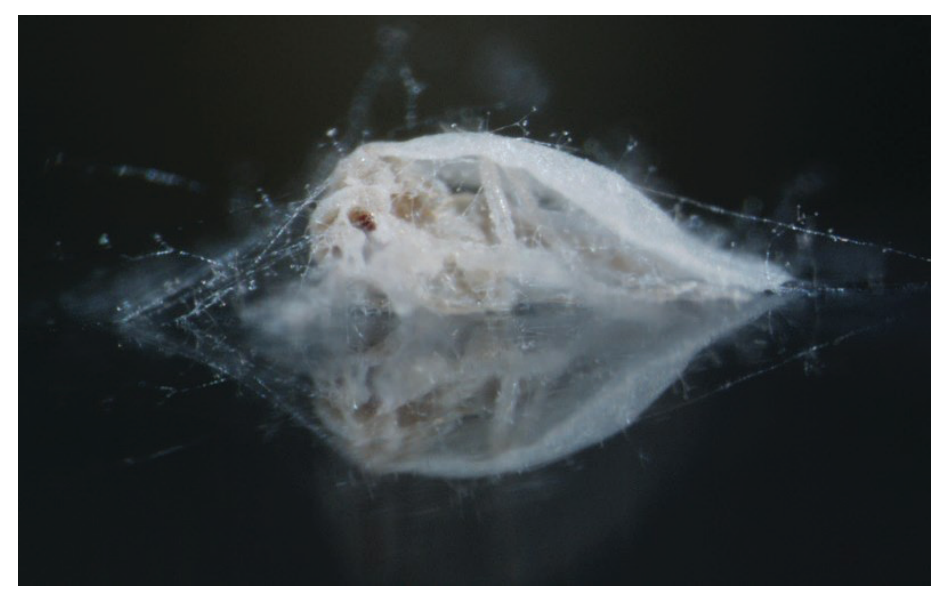

Figure 6. Whitefly adult infected by entomopathogenic fungi $B$. bassiana.

Credits: Lance S. Osborne, UF/IFAS

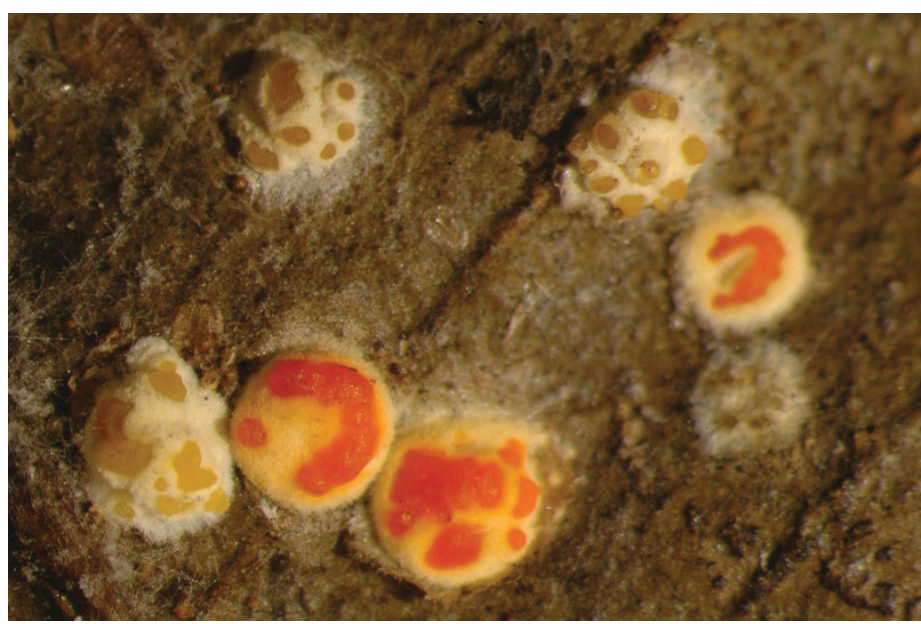

Figure 7. Whitefly nymphs infected by entomopathogenic fungi Aschersonia sp.

Credits: Lance S. Osborne, UF/IFAS

\section{Chemical Control}

If not selected correctly, chemicals can only provide a limited level of whitefly control. It is important to initiate application before the whitefly population increases to damage levels. Application timing should be based on residual activity of the pesticide instead of an established 5-7 days schedule. Many new insecticides have residual activity of greater than one week; check the product labels for specific reapplication intervals. However, it is highly recommended that no more than 2 to 3 applications be made during the entire growing season of compounds belonging to any single IRAC-Mode of Action Group and especially those in Group 4 to avoid undue selection for resistance (see tables). The insect growth regulators Talus and Distance should not be used more than twice during a crop cycle.

Growers should also utilize non-selective products such as soaps, oils, and biological controls when possible. It is highly recommended that any whiteflies in the facility be tested periodically for biotype because more management tools are available for MEAM1 than MED. Testing biotype is especially important if a product does not adequately control whiteflies. Select products based on the biotype of any whiteflies that are present. Follow all label guidelines for appropriate use sites, rates of application, reapplication intervals, and resistance management strategies. Pay very close attention to information on how to manage irrigation and soil moisture when using systemic products.

Following are the steps and criteria for selecting among different whitefly management programs.

Start with the Line 1 in the "Key to Tables for Suggested Whitefly Applications," and then work your way through 
the key to the growth stage of your crop. Then refer to the tables (A-F) for suggested products, which are listed with recommended "yes" or "no" in the tables for each biotype based on current research (Kumar et al. 2016a,b,c; Kumer et al. 2017a,b,c,d,e,f,g; Kumer et al. 2018a,b). In addition, Insecticide efficacy for $B$. tabaci MEAM1 and MED on Poinsettia is listed in Table G and the results of high and low rates efficacy trials of new chemistry insecticide against MED are listed in Table H-J. As you are developing your own personalized management plan, test products for crop safety on a small set of plants, and check label restrictions for a number of total applications per crop.

Key to tables for suggested whitefly applications

\section{Plants are Bemisia tabaci hosts}

a. Yes......................... 2

b. No......................... Done

\section{Plants are cuttings in propagation being rooted}

a. Yes........................... 3

b. No......................... 4

\section{Rooting level during propagation}

a. Mist on, cuttings are newly stuck and not anchore Table A

b. Mist off, cuttings are anchored in the soil and able to withstand spray applications Table B

\section{Plants are rooted cuttings and ready for shipment}

a. a. Yes........................ Table F

b. b. No.......................... 5

\section{Plant development after transplanting}

a. Root system is not well developed Table C

b. Roots are well developed and penetrating the soil to the sides and bottom of the pots

\section{Plants are actively growing finished plants or stock}

a. Plants are more than two weeks from shipment or first cutting harvest. Table D

b. Plants are two weeks from shipment or first cutting harvest. Table E

c. Plants or cuttings are 2 to 3 days from shipment Table F

\section{Whitefly Resistance Management}

There are multiple factors which can affect resistance development in a pest against a selected insecticide. The greater the number of whiteflies present when an insecticide application is made, the greater the chance that at least one individual might possess the ability to survive the treatment. The more frequently a given insecticide or mode of action is used, the greater the potential that a resistance problem will develop. In other words, selection for resistance in whiteflies against an insecticide can occur when their applications are made to successive generations of the pest. In addition, the longer the residual activity, the greater the selection pressure on a resident whitefly population.

Therefore, limiting applications of products with similar modes of action will decrease the potential for resistance development. If the insecticide is properly applied and is not providing control, change to another material with a different mode of action because whitefly populations have the propensity to develop resistance. Scouting every week is critical to success by catching populations early and evaluating insecticide performance during production. While rotating insecticides it is important to consider that IRAC Class 9B exhibits cross resistance with IRAC Class 4.

Tables $\mathrm{H}-\mathrm{J}$ presents different modes of action available for controlling MED whitefly and efficacy data of selected new chemistry insecticides against whitefly population when applied alone and in rotation (Kumar et al. 2016a,b,c; Kumar et al. 2017a,b,c,d,e,f,g; Kumar et al. 2018a,b). New chemistry data were presented only in tables $\mathrm{H}-\mathrm{J}$. We aim to add new chemistry data in tables A to $G$ in the near future.

\section{Acknowledgement}

We would like to thank all the contributors (James Bethke, Luis Canas, Joe Chamberlin, Ray Cloyd, Jeff Dobbs, Rick Fletcher, Dave Fujino, Dan Gilrein, Richard Lindquist, Scott Ludwig, Ron Oetting, Nancy Rechcigl, and John Sanderson) 
who helped in summarizing the efficacy results. This work was supported by funding from FNRI, NIFA, AFE, IRAC, the IR-4 Project, and ANLA.

\section{Laboratory Authorized to Determine Whitefly Biotype}

For information about how to collect whitefly samples and preserve it for evaluation and directions for scheduling shipments, you can contact:

Cindy McKenzie, Ph.D. Research Entomologist USDA, ARS, US Horticultural Research Laboratory 2001 South Rock Road

Fort Pierce, FL 34945 Phone: 772-462-5917

Email: cindy.mckenzie@ars.usda.gov

\section{Selected References}

Dennehy, T. J., B. A. Degain, V. S. Harpold, J. K. Brown, Morin, J. A. Fabrick, R. L. Nichols. 2005. "New challenges to management of whitefly resistance to insecticides in Arizona." The University of Arizona College of Agriculture and Life Sciences 2005 Vegetable Report. Available: http://arizona.openrepository.com/arizona/bitstream/10150/215014/1/ az1382_2-2005.pdf. Accessed on 9 August 2021.

Dickey, A. M., L. S. Osborne, R. G. Shatters, P. M. Hall, C. L. McKenzie. 2013. "Population genetics of invasive Bemisia tabaci (Hemiptera: Aleyrodidae) cryptic species in the United States based on microsatellite markers." Journal of Economic Entomology 106 (3): 1355-1364. https://doi. org/10.1603/EC12512

FDACS-DPI Database. 2021. Division of Plant Industry, Florida Department of Agriculture and Consumer Service, Gainesville, FL. Accessed on January 20, 2021.

Hoddle, M. 2013 (last updated). "The biology and management of the silverleaf whitefly, Bemisia argentifolii Bellows and Perring (Homoptera: Aleyrodidae) on greenhouse grown ornamentals." http://biocontrol.ucr.edu/bemisia. html. Accessed on 9 August 2021.

Horowitz, A. R., S. Kontsedalov, I. Ishaaya. 2004. "Dynamics of resistance to the neonicotinoids acetamiprid and thiamethoxam in Bemisia tabaci (Homoptera: Aleyrodidae)." Journal of Economic Entomology 97: 2051-2056. https://doi.org/10.1603/0022-0493-97.6.2051

Jiu, M., J. Hu, L. J. Wang, J. F. Dong, Y. Q. Song, H. Z. Sun. 2021. "Cryptic species identification and composition of
Bemisia tabaci (Hemiptera: Aleyrodidae) complex in Henan province, China." Journal Insect Science 17 (3): 78. https:// doi.org/10.1093/jisesa/iex048

Jones D. R. 2003. Plant viruses transmitted by whiteflies. European Journal Plant Pathology 109: 195-219.

Kumar, V., G. Kakkar,C. L. McKenzie, L. S. Osborne. 2016a. "Effect of soil application of cyantraniliprole on Bemisia tabaci (MED whitefly) and Amblyseius swirskii, 2016." Arthropod Management Tests. 41: tsw136 (Report).

Kumar, V., G. Kakkar, C. L.McKenzie, L. S. Osborne. 2016b. "Effect of foliar application of pyrifluquinazon on Bemisia tabaci (MED whitefly) and Amblyseius swirskii, 2016." Arthropod Management Tests 41: tsw135 (Report).

Kumar, V., G. Kakkar, C. L.McKenzie, L. S. Osborne. 2016c. "Effect of dinotefuran on Bemisia tabaci (MED whitefly) and Amblyseius swirskii, 2016." Arthropod Management Tests. 41: tsw100 (Report). https://doi.org/10.1093/amt/ tsw100

Kumar, V., G. Kakkar, C. L.McKenzie, L. S. Osborne. 2017a. "Impact of drench application of cyantraniliprole on Bemisia tabaci (MED whitefly) and Amblyseius swirskii, 2016." Arthropod Management Tests 42: tsx056 (Report). https://doi.org/10.1093/amt/tsx056

Kumar, V., G. Kakkar, C. L.McKenzie, L. S. Osborne. 2017b. "Effect of foliar application of pymetrozine on Bemisia tabaci (MED whitefly) and Amblyseius swirskii, 2016." Arthropod Management Tests. 42: tsx054 (Report). https:// doi.org/10.1093/amt/tsx054

Kumar, V., G. Kakkar, C. L.McKenzie, L. S. Osborne. 2017c. "Effect of foliar application of Xxpire on Bemisia tabaci (MED whitefly) and Amblyseius swirskii, 2016." Arthropod Management Tests 42: tsx077 (Report). https://doi. org/10.1093/amt/tsx077

Kumar, V., G. Kakkar, C. L. McKenzie,L. S. Osborne. 2017d. "Impact of pymetrozine on Bemisia tabaci (MED whitefly) and Amblyseiuss swirskii, 2017." Arthropod Management Tests 42: tsx129 (Report). https://doi.org/10.1093/amt/ tsx 129

Kumar, V., G. Kakkar, C. L. McKenzie,L. S. Osborne. 2017e. "Effect of drench application of flupyradifurone on Bemisia tabaci (MED whitefly) and Amblyseius swirskii, 2017." Arthropod Management Tests 42: tsx131 (Report). https:// doi.org/10.1093/amt/tsx131 
Kumar, V., G. Kakkar, C. L. McKenzie,L. S. Osborne. 2017 f. "Effect of foliar application of flupyradifurone on Bemisia tabaci (MED whitefly) and Amblyseius swirskii, 2017."

Arthropod Management Tests 42: tsx132, (Report). https:// doi.org/10.1093/amt/tsx132

Kumar, V., C. L. McKenzie, L. S. Osborne. 2018a. "Effect of foliar application of afidopyropen on Bemisia tabaci (MED whitefly) and Amblyseius swirskii, 2018." Arthropod Management Tests 43: tsy071 (Report). https://doi.org/10.1093/ amt/tsy107

Kumar, V., C. L. McKenzie, L. S. Osborne. 2018b. "Control of Bemisia tabaci (MED) on salvia using afidopyropen, 2018." Arthropod Management Tests 43: tsy107 (Report). https://doi.org/10.1093/amt/tsy107

Li Y. P., G. N. Mbata, S. Punnuri, A. M. Simmons, D. I. Shapirollan. 2021. "Bemisia tabaci on vgetables in the southern United States: incidence, impact, and management." Insects 12 (3):198. https://doi.org/10.3390/insects12030198

Lowe S., M. Browne, S. Boudjelas, M. De Poorter. 2000. 100 of the world's worst invasive alien species, A selection from the Global Invasive Species Database. The Invasive Species Specialist Group (ISSG), World Conservation Union (IUCN), pp. 6-7. http://www.issg.org/pdf/publications/ worst_100/english_100_worst.pdf

McKenzie, C. L., G. Hodges, L. S. Osborne, F. J. Byrne, R. G. Shatters, Jr. 2009. "Distribution of Bemisia tabaci (Hemiptera: Aleyrodidae) biotypes in Florida-investigating the Q invasion." Journal of Economic Entomology 102 (2) 670-676. https://doi.org/10.1603/029.102.0227

McKenzie, C. L., J. A. Bethke, F. J. Byrne, J. R. Chamberlin, S. J. Dennehy, A. M. Dickey, D. Gilrein, P. M. Hall, S.

Ludwig, R. D. Oetting, L. S. Osborne, L. Schmale, and R. G. Shatters. 2012. "Distribution of Bemisia tabaci (Hemiptera: Aleyrodidae) biotypes in North America following the Q invasion." Journal of Economic Entomology 105: 753-766. https://doi.org/10.1603/EC11337

McKenzie, C. L., V. Kumar, C. L. Palmer, R. D. Oetting, L. S. Osborne. 2014. "Chemical class rotations for control of Bemisia tabaci (Hemiptera: Aleyrodidae) on poinsettia and their effect on cryptic species population composition." Pest Management Science 70: 1573-1587. https://doi. org/10.1002/ps.3736
McKenzie, C. L., L. S. Osborne. 2017. “Bemisia tabaci MED (Q biotype) (Hemiptera: Aleyrodidae) in Florida is on the move to residential landscapes and May impact open-field agriculture." Florida Entomologist 100 (2):481-484. https:// doi.org/10.1653/024.100.0213

McKenzie, C. L., Sparks, Jr., A. N., Roberts, P., Oetting, R., and Osborne, L. S. 2020. "Survey of Bemisia tabaci (Hemiptera: Aleyrodidae) in agricultural ecosystems in Georgia." Journal of Entomological Science 55 (2):163-170. https://doi. org/10.18474/0749-8004-55.2.163

Parrella, M. P., R. J.Gill, J. K.Brown, K. M.Heinz. 1992. "Sweetpotato whitefly: prospects for biological control."California Agriculture 46 (1): 25-26. https://doi. org/10.3733/ca.v046n01p25

Perring, T. M., A. D. Cooper, R. J. Rodriguez, C. A. Farrar, T. S. Bellows Jr. 1993. "Identification of a whitefly species by genomic and behavioral studies." Science 259 (5091): 74-77. https://doi.org/10.1126/science.8418497 
Table A. Cuttings are not anchored in soil.

\begin{tabular}{|l|l|l|l|}
\hline \multicolumn{1}{|c|}{ Suggested products } & \multicolumn{1}{|c|}{ IRAC class } & MEAM1 & MED \\
\hline Foggers and aerosol generators & Many & Yes & Yes \\
\hline
\end{tabular}

Table B. Cuttings able to withstand sprays.

\begin{tabular}{|l|c|c|c|}
\hline \multicolumn{1}{|c|}{ Suggested products } & IRAC Class & MEAM1 & yes \\
\hline Foggers & many & yes & yes \\
\hline Avid (abamectin) + pyrethroid or acephate & $6+3$ or 1 & yes & yes \\
\hline Beauveria bassiana & n/a & yes & yes \\
\hline PFR-97 (Isaria fumosorosea) & n/a & yes \\
\hline
\end{tabular}

Table C. Root system is not well developed.

\begin{tabular}{|l|c|c|c|}
\hline \multicolumn{1}{|c|}{ Suggested products } & IRAC class & MEAM1 & MED \\
\hline Avid (abamectin) & 6 & Yes & Yes \\
\hline Distance (pyriproxyfen) & $7 C$ & Yes & No \\
\hline Endeavor (pymetrozine) & $9 B^{*}$ & Yes & No \\
\hline Enstar II (kinoprene) & $7 \mathrm{~A}$ & Yes & Yes \\
\hline Sanmite (pyridaben) & 21 & Yes & No \\
\hline Talus (buprofezin) & 16 & Yes & \\
\hline Tank mixes & & & \\
\hline Avid + Talstar & $6+3$ & Yes & Yes \\
\hline Pyrethroids + acephate & $3+1$ & Yes & No \\
\hline Pyrethroids + azadirachtin & $3+18$ & Yes & No \\
\hline
\end{tabular}

Table D. Plants are actively growing.

Select products based on the biotype of any whiteflies that are present. Rotating products during this production stage is essential. Where plants are tolerant, tank mix with horticultural oil to help minimize resistance development. Not all poinsettia cultivars are tolerant to Judo or Kontos during bract color development; it is recommended to apply these prior to bract formation and test on a small number of plants prior to spraying entire crop.

\begin{tabular}{|c|c|c|c|}
\hline $\begin{array}{l}\text { Suggested products for foliar } \\
\text { applications on actively } \\
\text { growing plants }\end{array}$ & IRAC class & MEAM1 & MED \\
\hline Avid + Pyrethroid & $6+3$ & Yes & Yes \\
\hline Beauveria bassiana & $\mathrm{n} / \mathrm{a}$ & Yes & Yes \\
\hline Bug Oil (tagetes oil) & $\mathrm{n} / \mathrm{a}$ & - & Yes \\
\hline Distance (pyriproxyfen) & $7 C$ & Yes & No \\
\hline Enstar II (kinoprene) & $7 \mathrm{~A}$ & Yes & No \\
\hline Horticultural oil & $\mathrm{n} / \mathrm{a}$ & Yes & Yes \\
\hline Insecticidal soap & $\mathrm{n} / \mathrm{a}$ & Yes & Yes \\
\hline Judo (spiromesifen) & 23 & Yes & Yes \\
\hline Kontos (spirotetramat) & 23 & Yes & Yes \\
\hline M-Pede & $\mathrm{n} / \mathrm{a}$ & Yes & Yes \\
\hline Orthene + pyrethroid & $1+3$ & Yes & No \\
\hline PFR-97 & $\mathrm{n} / \mathrm{a}$ & Yes & Yes \\
\hline Rycar (pyrifluquinazon) & $9 \mathrm{~B}$ & Yes & Yes \\
\hline Sanmite (pyridaben) & 21 & Yes & Yes \\
\hline Talus (buprofezin) & 16 & Yes & No \\
\hline
\end{tabular}


Table E. Plants are two weeks from shipment or first cutting harvest.

Control of whiteflies is often challenging during this stage due to the difficulty of achieving adequate under leaf spray coverage, a lack of labeled products from multiple IRAC Classes, and concerns about phytotoxicity or residue on final product. Apply a drench or foliar application 14 days prior to shipment of finished plants or the initial harvest of cuttings from stock plants. If adequate spray coverage cannot be achieved, plants should be drenched. To reduce resistance development, do not use products listed in Table E that were applied prior to this growing stage. If multiple cutting harvests are taken from stock plants, rotate a neonicotinoid drench application (IRAC Group 4) with foliar applications of Judo and Sanmite, including other products as needed from Table D in different IRAC Classes.

\begin{tabular}{l|l|l|l|}
$\begin{array}{c}\text { Suggested products for plants or } \\
\text { stock plants }\end{array}$ & IRAC class & MEAM1 \\
\hline
\end{tabular}

\section{Soil drench or foliar applications}

Flagship (thiamethoxam)

Marathon (imidacloprid)

Safari (dinotefuran)

\begin{tabular}{l|l}
\hline+2 \\
\hline
\end{tabular}

\begin{tabular}{|l|l|}
\hline 4 & \\
\hline 4 & \\
\hline 4 & \\
\hline
\end{tabular}

\begin{tabular}{|c|c|}
\hline Yes & Yes \\
\hline Yes & No \\
\hline Yes & Yes \\
\hline
\end{tabular}

Soil drench

\begin{tabular}{|l|c|c|c|}
\hline Mainspring (cyantraniliprole) & 28 & Yes & Yes \\
\hline Foliar applications & \multicolumn{2}{|c|}{ Yes } \\
\hline PFR-97 & n/a & Yes & Yes \\
\hline Rycar (pyrifluquinazon) & $9 B$ & Yes & Yes \\
\hline Sanmite (pyridaben) & 21 & Yes & Yes \\
\hline TriStar (acetamiprid) & 4 &
\end{tabular}

Table F. Plants or harvested cuttings are $2-3$ days before shipping.

Make foliar applications 2-3 days before shipping finished plants or rooted cuttings or before each cutting harvest when shipping unrooted cuttings. To reduce resistance development, avoid applications of modes of action used in the previous growth stage (Table $E$ for finished plants or stock, and Table B for rooted cuttings).

\begin{tabular}{|l|c|c|}
\hline \multicolumn{1}{|c|}{ Suggested products for harvested cuttings } & IRAC class & MEAM1 \\
\hline Avid (abamectin) & 6 & MED \\
\hline Flagship (thiamethoxam) & 4 & Yes \\
\hline $\begin{array}{l}\text { Judo (spiromesifen)_targeting nymphs at this plant stage for unrooted cuttings or } \\
\text { cultivars tested for crop safety }\end{array}$ & 23 & Yes \\
\hline PFR-97 & n/a & Yes \\
\hline Safari (dinotefuran) & 4 & Yes \\
\hline Sanmite (pyridaben) & 21 & Yes \\
\hline TriStar (acetamiprid)_targeting adults at this plant stage & 4 & Yes \\
\hline
\end{tabular}




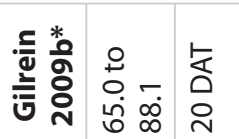

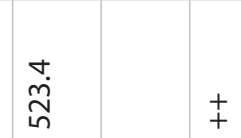

\begin{tabular}{l|l|l|l}
+ & \\
+ & &
\end{tabular}

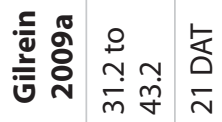

$\stackrel{\substack{\infty \\ \infty}}{\stackrel{2}{\sim}}$

\begin{tabular}{l|l|l|l|l}
\hline & & & & \\
+ & & & + & +
\end{tabular}

$\mid$

Oั

$+\frac{1}{+}$

$+$

$\overline{0}$

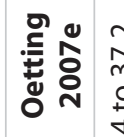

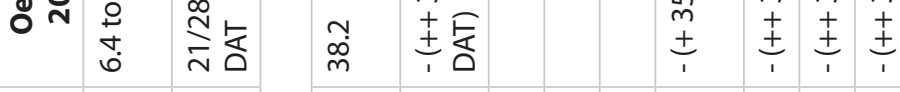

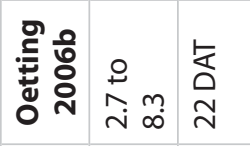

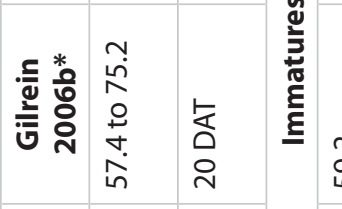

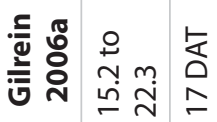

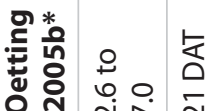

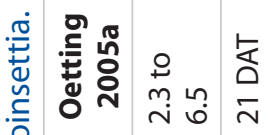

岂

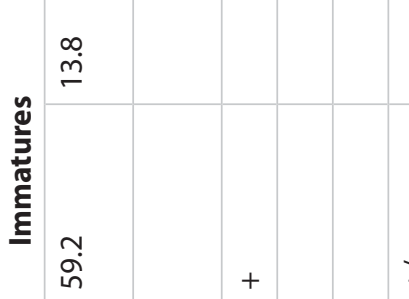

$++++$

$++$

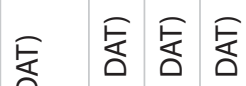

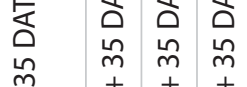

\begin{tabular}{llll|l}
1 & 1 & 1 & \pm & +
\end{tabular}

$\begin{array}{lll}0 & m \\ + & + \\ + & & \\ + & \end{array}$

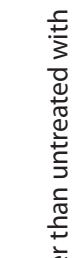

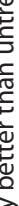

$\frac{d}{\frac{0}{0}}$

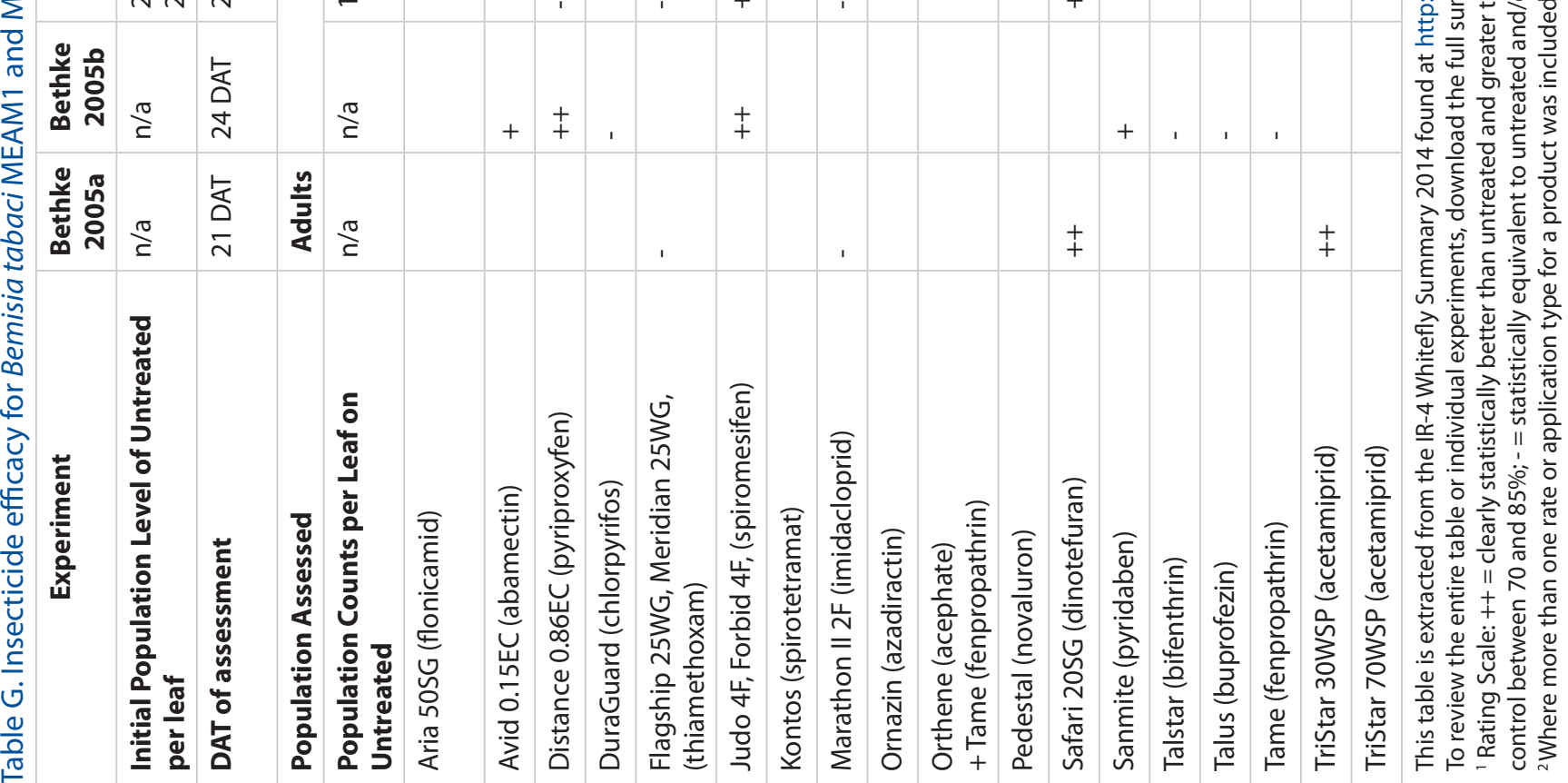


Table H. Summary of new insecticide efficacy trials (2016-2018) on potted salvia plants at the high label rates.

\begin{tabular}{|c|c|c|c|c|c|}
\hline Tested Products for Actively Growing Plants & $\begin{array}{l}\text { IRAC } \\
\text { Class }\end{array}$ & $\begin{array}{l}\text { Rate / Method } \\
\text { Per } 100 \text { gallons }\end{array}$ & $\begin{array}{l}\% \text { Control } \\
\text { MED WF* }\end{array}$ & $\begin{array}{c}\text { MED } \\
\text { (effective) }\end{array}$ & $\begin{array}{l}\text { Compatible with } \\
\text { swirskii mite }\end{array}$ \\
\hline Safari (dinotefuran) & $4 \mathrm{~A}$ & $12 \mathrm{oz} /$ Drench & $97.2 \%$ & Yes & Yes \\
\hline Mainspring (cyantraniliprole) & 28 & 12 fl oz / Drench & $92-96 \%$ & Yes & Yes \\
\hline Rycar (pyrifloquinazon) & $9 B$ & $1.6 \mathrm{fl} \mathrm{oz} \mathrm{/} \mathrm{Foliar}$ & $91-95 \%$ & Yes & Yes \\
\hline Altus (flupyradifurone) & $4 \mathrm{D}$ & $\begin{array}{l}21 \mathrm{fl} \mathrm{oz} \mathrm{/} \mathrm{Drench} \\
10.5 \mathrm{fl} \mathrm{oz} \mathrm{/} \mathrm{Foliar}\end{array}$ & $\begin{array}{l}76-81 \% \\
71-73 \%\end{array}$ & Yes & Yes \\
\hline Ventigra (Afidopyropen) & $9 D$ & $7 \mathrm{fl} \mathrm{oz} \mathrm{/} \mathrm{Foliar}$ & $85-94 \%$ & Yes & Yes \\
\hline Xxpire (spinetoram + Sulfoxaflor) & $4 C+5$ & $2.75 \mathrm{oz} /$ Foliar & $77-89 \%$ & Yes & No \\
\hline Endeavor (pymetrozine) & $9 \mathrm{~B}$ & $5+10 \mathrm{oz} /$ Foliar & $39-50 \%$ & No & Yes \\
\hline
\end{tabular}

Note: There are three types of MED whitefly present in the United States; efficacy of an insecticide may vary depending upon the MED population. These trials were conducted on Western MED. Mention of a commercial or proprietary product or chemical does not constitute a recommendation or warranty of the product by the authors. Products should be used according to label instructions, and safety equipment required on the label and by federal or state law should be employed. Users should avoid the use of chemicals under conditions that could lead to ground water contamination. Pesticide registrations may change, so it is the responsibility of the user to ascertain if a pesticide is registered by the appropriate local, state and federal agencies for an intended use. Trademarks and registered trademarks for mentioned products or chemicals belong to their respective owners.

Table I. Summary of new insecticide efficacy rotation trials on potted salvia plants with moderate adult MED whitefly infestation at low label rates.

\begin{tabular}{|l|l|l|l|l|c|c|}
\hline \multicolumn{1}{|c|}{ Rotation 1 } & $\begin{array}{l}\text { Rotation 1 } \\
\text { (\% Control } \\
\text { MED WF*) }\end{array}$ & \multicolumn{1}{|c|}{ Rotation 2 } & $\begin{array}{l}\text { Rotation 2 } \\
\text { (\% Control } \\
\text { MED WF*) }\end{array}$ & \multicolumn{1}{|c|}{$\begin{array}{c}\text { Rotation 3 } \\
\text { Seasonal } \\
\text { (\% Control } \\
\text { MED WF*) }\end{array}$} \\
\hline Mainspring (28) D & $35.1 \%$ & Rycar (9B) F & $92.9 \%$ & Altus (4D) F & $97.5 \%$ \\
\hline Rycar (9B) F & $81.5 \%$ & Altus (4D) D & $92.6 \%$ & Mainspring (28) F & $91.3 \%$ \\
\hline Altus (4D) D & $15.1 \%$ & Mainspring (28) F & $53.4 \%$ & Ventigra (9D) F & $91.9 \%$ \\
\hline Mainspring (28) F & $46.1 \%$ & Avid (6) F & $87.5 \%$ & Altus (4D) D & $77.6 \%$ \\
\hline Altus (4D) F & $68.1 \%$ & Ventigra (9D) F & $92.9 \%$ & Avid (6) F & $97.1 \%$ \\
\hline Avid (6) F & $39.4 \%$ & Altus (4D) D & $72.7 \%$ & Ventigra (9D) F & $94.5 \%$ \\
\hline
\end{tabular}

Note: *Adult MED WF, WF=Whiteflies, $\mathrm{D}=$ Drenching, $\mathrm{F}=$ Foliar. Foliar applications performed better than drenches at the low label rates. Data was taken three weeks after application in each rotation. Active ingredients and rate per 100 gallons of Altus (flupyradifurone)=10.5 fl oz, Avid (abamectin) $=8 \mathrm{fl} \mathrm{oz}$, Ventigra (Afidopyropen)=4.8 fl oz, Mainspring (cyantraniliprole)=2 fl oz, Rycar (pyrifloquinazon)=1.6 fl oz.

Table J. Summary of new insecticide efficacy rotation trials on potted salvia plants with high adult MED whitefly infestation at low label rates.

\begin{tabular}{|c|c|c|c|c|c|c|}
\hline Rotation 1 & $\begin{array}{c}\text { Rotation } 1 \\
\text { (\% Control MED } \\
\text { WF*) }\end{array}$ & Rotation 2 & $\begin{array}{c}\text { Rotation } 2 \\
\text { (\% Control MED } \\
\text { WF*) }^{*}\end{array}$ & Rotation 3 & $\begin{array}{c}\text { Rotation } 3 \\
\text { (\% Control MED } \\
\text { WF*) }\end{array}$ & $\begin{array}{c}\text { Seasonal } \\
\text { (\% Control MED } \\
\text { WF*) }\end{array}$ \\
\hline Mainspring (28) D & $27.5 \%$ & Rycar (9B) F & $95.7 \%$ & Altus (4D) F & $98.5 \%$ & $80.1 \%$ \\
\hline Rycar (9B) F & $82.5 \%$ & Altus (4D) D & $92.9 \%$ & Mainspring (28) F & $91.4 \%$ & $89.8 \%$ \\
\hline Altus (4D) D & $12.5 \%$ & Mainspring (28) F & $55.0 \%$ & Ventigra (9D) F & $85.4 \%$ & $56.6 \%$ \\
\hline Mainspring (28) F & $50.3 \%$ & Avid (6) F & $79.3 \%$ & Altus (4D) D & $72.7 \%$ & $68.9 \%$ \\
\hline Altus (4D) F & $40.0 \%$ & Ventigra (9D) F & $85.8 \%$ & Avid (6) F & $89.4 \%$ & $76.1 \%$ \\
\hline Avid (6) F & $39.7 \%$ & Altus (4D) D & $67.7 \%$ & Ventigra (9D) F & $86.3 \%$ & $68.2 \%$ \\
\hline Rycar (9B) F & $73.2 \%$ & Altus (4D) F & $89.6 \%$ & Avid (6) F & $97.7 \%$ & $93.7 \%$ \\
\hline Avid (6) F & $56.1 \%$ & Rycar (9B) F & $88.3 \%$ & Altus (4D) F & $98.2 \%$ & $92.3 \%$ \\
\hline Altus (4D) F & $48.0 \%$ & Avid (6) F & $85.1 \%$ & Rycar (9B) F & $98.7 \%$ & $91.2 \%$ \\
\hline Oil (F) & $9.8 \%$ & Oil (F) & $36.5 \%$ & Oil (F) & $34.4 \%$ & $29.4 \%$ \\
\hline
\end{tabular}

Note: *Adult MED WF, WF=Whiteflies, D=Drenching, F=Foliar. Foliar applications performed better than drenches at the low label rates. Data was taken three weeks after application in each rotation. Active ingredients and rate per 100 gallons of Altus (flupyradifurone)=10.5 fl oz, Avid (abamectin) $=8 \mathrm{fl} \mathrm{oz}$, Ventigra (Afidopyropen) $=4.8 \mathrm{fl} \mathrm{oz}$, Mainspring (cyantraniliprole) $=2 \mathrm{fl} \mathrm{oz,} \mathrm{Purespray} \mathrm{Green} \mathrm{(Petroleum} \mathrm{Oil)=128} \mathrm{fl} \mathrm{oz,} \mathrm{Rycar}$ (pyrifloquinazon) $=1.6 \mathrm{fl} \mathrm{oz}$. 